San Jose State University

SJSU ScholarWorks

Master's Projects

Master's Theses and Graduate Research

Spring 2018

\title{
Benchmarking the Delivery of FEMA Training to Operation Line Employees within Surface Transit Agencies
}

\author{
Matthew E. McCann \\ San Jose State University
}

Follow this and additional works at: https://scholarworks.sjsu.edu/etd_projects

Part of the Emergency and Disaster Management Commons, Policy Design, Analysis, and Evaluation Commons, Public Administration Commons, and the Transportation Commons

\section{Recommended Citation}

McCann, Matthew E., "Benchmarking the Delivery of FEMA Training to Operation Line Employees within Surface Transit Agencies" (2018). Master's Projects. 589.

DOI: https://doi.org/10.31979/etd.h5je-79eb

https://scholarworks.sjsu.edu/etd_projects/589

This Master's Project is brought to you for free and open access by the Master's Theses and Graduate Research at SJSU ScholarWorks. It has been accepted for inclusion in Master's Projects by an authorized administrator of SJSU ScholarWorks. For more information, please contact scholarworks@sjsu.edu. 


\title{
Benchmarking the Delivery of FEMA Training to Operation Line Employees within Surface Transit Agencies
}

\author{
by \\ Matthew E. McCann \\ A Thesis Quality Research Paper \\ Submitted in Partial Fulfillment of the \\ Requirements for the \\ Master's Degree
}

In

PUBLIC ADMINISTRATION

Prof. Frances Edwards. Ph.D.

Adviser

The Graduate School

San Jose State University

May 1, 2018 


\section{Table of Contents}

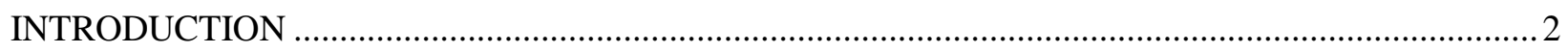

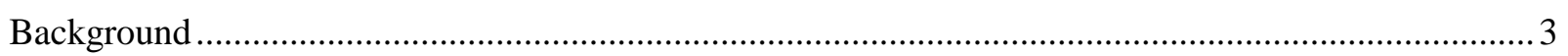

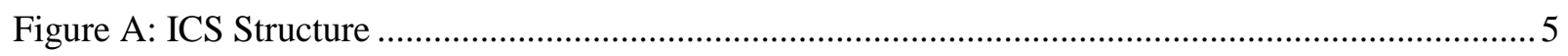

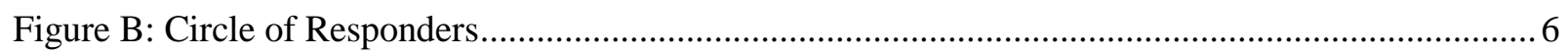

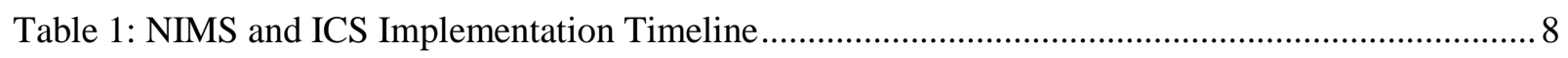

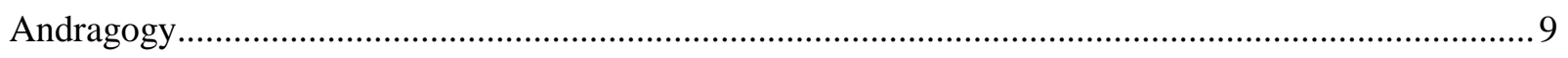

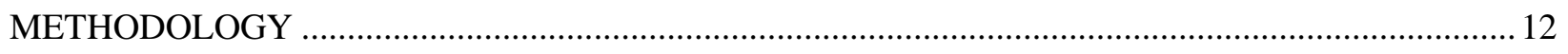

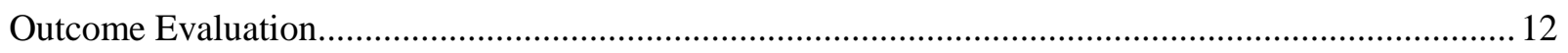

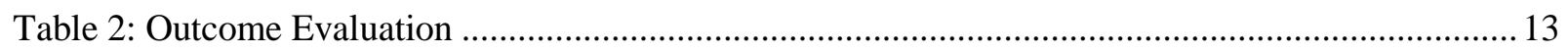

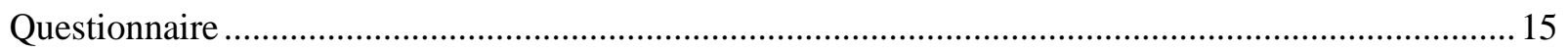

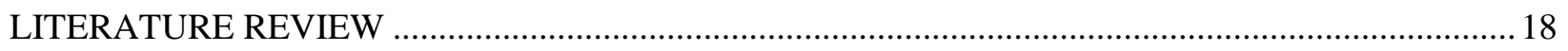

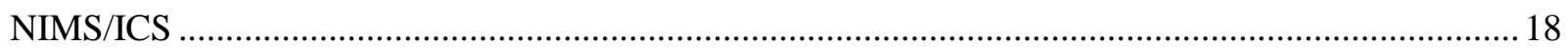

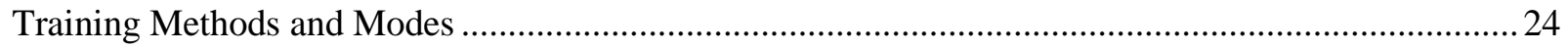

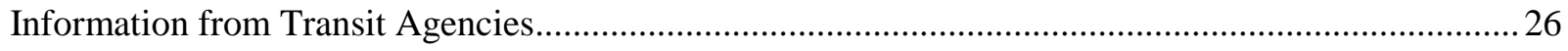

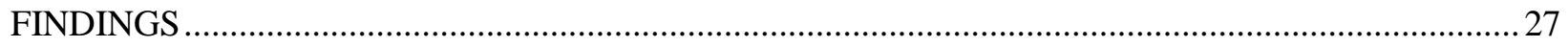

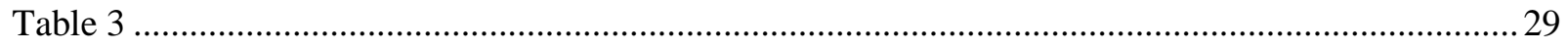

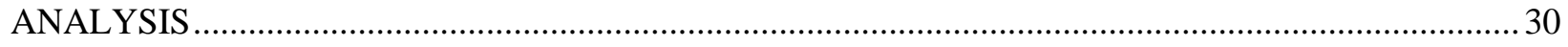

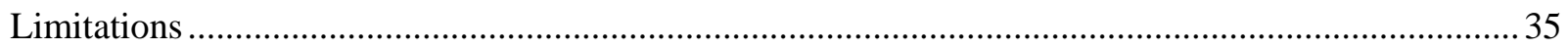

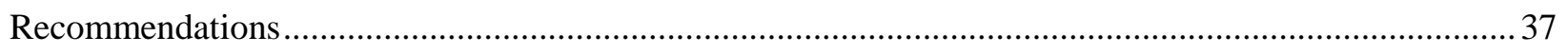

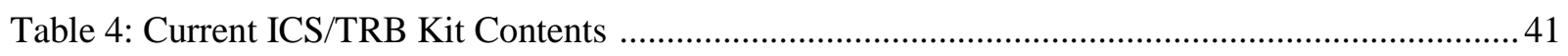

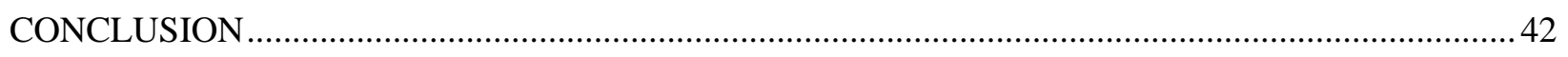

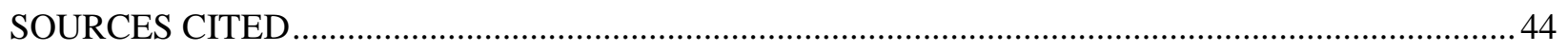

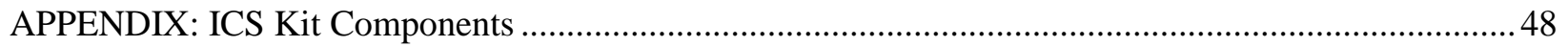

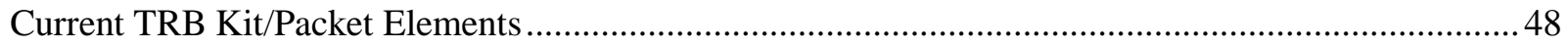




\section{INTRODUCTION}

In February 2003, in the aftermath of the September 11, 2001 terror attacks, the administration of then President George W. Bush developed Homeland Security Presidential Directive-5 (HSPD5), which mandated the use of the National Incident Management System (NIMS), and the Incident Command System (ICS) by all agencies receiving federal funding (Bush, 2003). The intent of HSPD-5 was to "enhance the ability of the United States to manage domestic incidents by establishing a single, comprehensive national incident management system" (Bush, 2003), or in other words, to ensure that emergency response by the many disparate agencies under the umbrella of government funding is using the same tools, resources, and operating concepts when they respond to an event; an alignment of mission. Because surface transit agencies fall under the HSPD-5 mandate and are an essential pillar in state, local, and national emergency response, it is important to understand how these agencies are presently implementing the HSPD-5 mandate to operation line employees receiving ICS 100/200 training. Therefore, this paper will identify the current delivery method employed for FEMA mandated Incident Command System (ICS) 100/200 training (e.g. online-only, face-to-face, or blended) for operation line employees at a few select surface transit agencies from broadly similarly sized metro areas, in different regions of the United States, and how the delivery of this training can be made more effective.

The specific surface transportation agencies that will be examined are the Santa Clara County Valley Transit Authority (SCCVTA), the Southeastern Pennsylvania Transit Authority (SEPTA), the Delaware River Port Authority (DRPA), and the Pinellas Suncoast Transit Authority (PSTA). These agencies were chosen because they service a broadly similar number of citizens, exhibit a distinct geographical and regional diversity, and because of the different threats that they face based on the disparate geographic regions from which they operate. These 
factors will allow for a more general assessment of NIMS/ICS implementation, and what factors, if any, serve to impede implementation as well as issues related to the deployment of NIMS/ICS in the event of a real-world scenario. In assessing the ability to deploy NIMS/ICS effectively in the field this document will examine the perceived efficacy of various teaching methodologies: online-only, face-to-face, or blended. Finally, the paper will seek to determine the agency's satisfaction with the current training methods employed by the agency, as well as identify any factors that might qualitatively improve ICS 100/200 learner outcomes; what they might change about current training. Ultimately, the goal is to increase understanding of the ICS 100/200 training methods employed by transit agencies, identify areas that might be suggestive of improvement, and provide recommendations that align with both the mandate and the needs of the organizations.

\section{Background}

The Incident Command System (ICS), and NIMS have origins in the state of California. In 1970, California was dealing with several devastating wildfires that would ultimately involve both Los Angeles City and County fire resources, and would result in a substantial loss of life, and property (Moynihan, 2008). Following the events of that year, there was a retrospective examination regarding potential shortcomings in the response to the fires which would eventually find that while various fire agencies did cooperate, the cooperation was deemed to be unsatisfactory by both responding agencies (Moynihan, 2008). It was determined that there was an imminent need to develop the capacity for more resource coordination in response to major events in the future (Moynihan, 2008).

The outcome of this post-event evaluation would eventually evolve into Fire Resources of Southern California Organized for Potential Emergency, or FIRESCOPE which helped to 
develop better cooperation across departments (Neamy, 2011). FIRESCOPE and the Los Angeles Fire Department would later implement an Incident Command System which sought to address the broad, and disparate challenges that a department might encounter during an emergency response effort (Neamy, 2011). These early efforts by fire departments in southern California evolved into a statewide emergency response plan that has had a lasting impact on the citizens of that state. Of note is the critical importance of cross-department cooperation, and consistency in response, which serve to reduce waste and save time before, during, and after an incident has taken place.

After 9/11 President George W. Bush issued HSPD-5 which established NIMS as a requirement for all agencies receiving federal funding (HSPD-5, 2005). Housed within the NIMS structure is the framework established earlier within the state of California - specifically the Incident Command System (Figure A) (Neamy, 2011). 


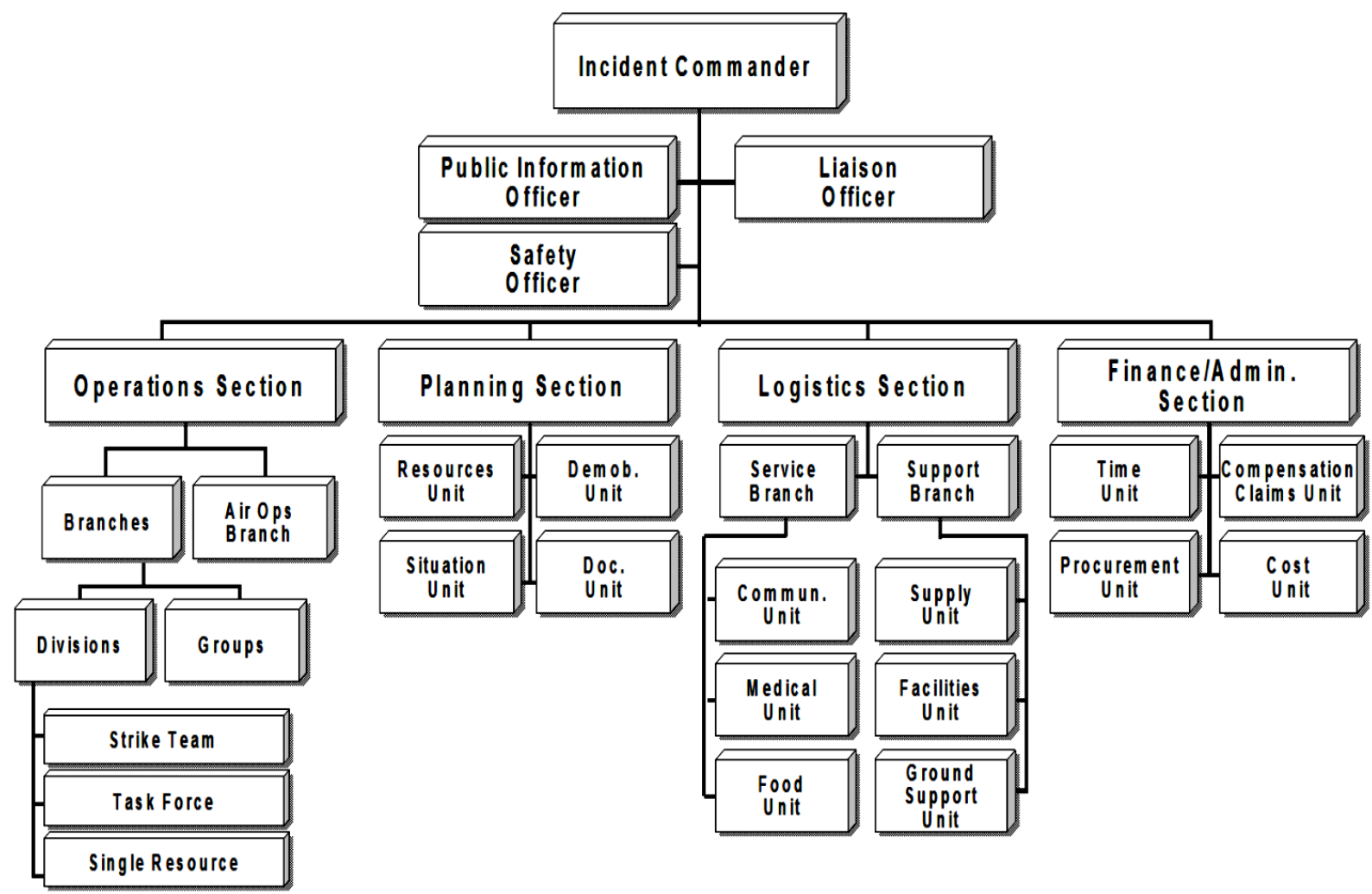

Source: Golobish, 2012, p.1

The Incident Command System, or ICS, while previously implemented and refined in California, further demonstrated its efficacy in the response to the 9/11 attack on the Pentagon, which resulted in rapid reaction to the event, while resulting in no death or severe injury to first responders (Howitt, Leonard, 2009, p.268). The use of ICS by departments/agencies responding to the attack at the Pentagon placed NIMS/ICS on the radar of the federal government, which was now looking for a method that provided greater "mission-alignment" and coordination in resolving emergency incidents. 
HSPD-5 sought to establish a uniform, and comprehensive mode of response to "prevent, prepare, respond, and recover" from a variety of threats, from terrorism to natural disasters; and unified efforts across all levels of government (Bush, 2003). The mandate was intended to ensure a consistency of response from agencies which are often charged with widely divergent tasks within the emergency response framework. These agencies range from Figure B: Circle of Responders those specifically charged with emergency response, such as "first responders" (Police, Fire, Emergency Medical Personnel), to agencies that must work alongside them and assist in providing effective event management. Within the realm of emergency responders there are several concentric circles of different agencies (Figure B),

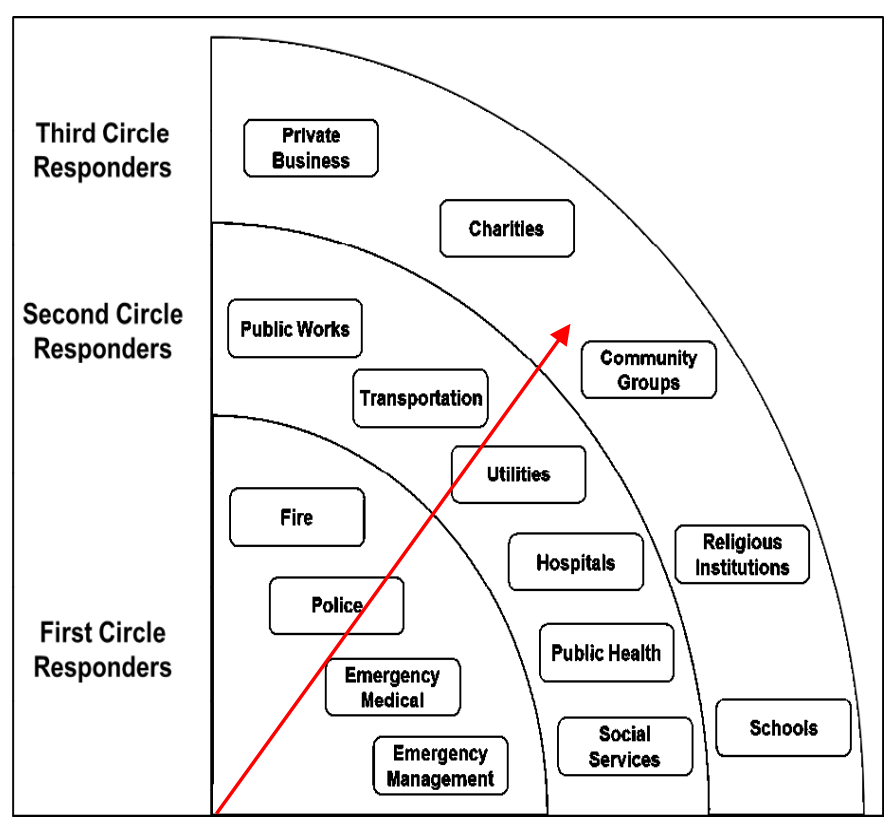

Source: Hambridge, Howitt, Giles, 2017, p.7 all charged with having a consistent response mechanism that uses NIMS (Hambridge, Howitt, Giles, 2017). While the term "first responder" indicates the immediacy of the response and the "core" placement of these agencies within emergency response, many of the agencies which radiate outward provide critical services and support in the event of an emergency, or during the recovery phase. Within the Second Circle responders are several different actors, including transportation. Transportation agencies are an essential element to emergency response, though they are not primarily "emergency-focused, this is 
because the transportation agencies often work alongside first responders responding to emergency scenarios" (Hambridge, Howitt, Giles, 2017, p.7-8).

Contemporaneous to HSPD-5, there was an assessment of emergency preparedness within the transportation sector conducted by the Federal Transit Administration (FTA), which led to the creation of the Special Committee on Transportation Security and Emergency Management (SCOTSEM) (Hambridge, Howitt, Giles, 2017, p. 9). The SCOTSEM group eventually developed several documents which were focused on transportation agency response, but these documents were primarily focused on terror threats (Hambridge, Howitt, Giles, 2017). However, after Hurricane Katrina hit the Gulf Coast region in 2005, the transportation sector again shifted its focus, this time towards recognition of "all hazards," and towards a more generalized approach to emergency management rather than the previous terror-event focused preparation (Hambridge, Howitt, Giles, 2017, p. 9). Likewise, the BP oil spill in the Gulf of Mexico laid bare the necessity of reexamining the nation's contingency plans and their ability to meet disparate challenges (Harrald, 2012) which had been overlooked in the flood of attention around external threats to the nation's transit systems. It was during this time that both the United States Department of Transportation (USDOT), and the Transportation Research Board (TRB) began efforts to promote NIMS related trainings in ICS, (Hambridge, Howitt, Giles, 2017, pp. 9-10), such as ICS 100/200, which are the primary focus of this document. These actions sought to institutionalize the use of NIMS within transit agencies, such as surface transportation, and to establish the processes through which NIMS/ICS are deployed in the event of an emergency (Table 1). 
Table 1: NIMS and ICS Implementation Timeline

\begin{tabular}{|l|c|c|}
\hline \multicolumn{1}{|c|}{ Product Required } & $\begin{array}{c}\text { HSPD-5 } \\
\text { Target Date }\end{array}$ & $\begin{array}{c}\text { Date } \\
\text { Achieved }\end{array}$ \\
\hline Initial version of NRP & $4 / 1 / 03$ & $5 / 14 / 03$ \\
\hline Draft NIMS standards, guidelines, and protocols & $6 / 1 / 03$ & $7 / 1 / 03$ \\
\hline $\begin{array}{l}\text { Identification of legislative changes necessary to implement } \\
\text { draft NRP }\end{array}$ & $9 / 1 / 03$ & $2 / 25 / 04$ \\
\hline Final draft NIMS & & $2 / 10 / 04$ \\
\hline Final NIMS & & $3 / 04$ \\
\hline Final NRP & & $12 / 04$ \\
\hline All departments to be NIMS compliant & $8 / 1 / 03$ & $10 / 1 / 05$ \\
\hline $\begin{array}{l}\text { All recipients of federal grants and contracts to be NIMS } \\
\text { compliant }\end{array}$ & $10 / 1 / 04$ & $10 / 1 / 06$ \\
\hline
\end{tabular}

Source: Harrald, 2012, p. 176

The current ICS 100/200 mandate/NIMS training program covers all "federal, state, territorial, local, tribal, private sector and non-governmental personnel " (Department of Homeland Security, 2011, p.3). This extends from emergency managers throughout an organization, down to the operation line employees who are responsible for day-to-day operations, often making them the first on-seen personnel at an incident.

The ICS 100 mandate specifically requires that these employees understand the following concepts:

- $\underline{\text { ICS overview }}$

- Basic features of ICS

- Incident commander and command staff functions

- General staff functions

- $\underline{\text { Facilities }}$

- Common responsibilities

(Department of Homeland Security, 2011, p.30) 


\section{ICS 200:}

- Define ICS organization appropriate to complexity of incident or event

- ICS to manage events

- Leadership and management

- Delegation of authority \& management by objective

- Functional areas and positions

- Organizational flexibility

- $\quad$ Transfer of Command

(Department of Homeland Security, 2011, p.32)

\section{Andragogy}

The employees who fall under the federal mandate placed on transit agencies are overwhelmingly adult learners, and as such it is essential to define what the learning process is, what it means to the learner, and provide context for how the training is administered by the agency or its representatives. Andragogy specifically address the teaching of adults (MerriamWebster, 2018), or in other words, a working hypothesis that would establish the "scientific fundamentals" of educators and students regarding the "planning, realizing, evaluating and correcting adult learning" (Zmeyov, 1998, p.4). The learner in this case is typically a "selfdirected, responsible person" who benefits from due consideration of their "life context" (Edwards, Goodrich, Griffith, 2016, p.21) (Zmeyov, 1998, p.4) which suggests that understanding and respecting the occupational/work experience that the learner already possesses should be leveraged to assist in the training process. Additionally, including features such as 
“in-class discussions, group work, and examining real-world scenarios" helps to compliment the delivery of training to adult learners (Edwards, Goodrich, Griffith, 2016, p.21).

The mandate requiring the training of operation line employees at transit agencies was established without any specific provisions to guide how the training is administered, only that they "be consistent with the concepts, principles and characteristics of the ICS training offered by the various DHS training entities" (FEMA, 2004). This leaves ample room for some variability in how the mandated ICS 100/200 training is delivered to the employees in question. Because of this, training methods that will be examined include online only, face-to-face, and blended. The online only training consists solely of the training modules and testing system hosted at the FEMA.gov website for use in fulfilling the mandate for ICS 100 and 200, which provide both information on the essential elements of both sections, as well as a test which upon completion generates a certificate which is sent in digital form to the test-taker's e-mail address, who is then responsible for delivering it to his department head. Online training complies with certain aspects of andragogy, in that many adult learners are, as previously mentioned, both “self-directed and responsible" (Zmeyov, 1998, p.4), however, it potentially neglects other learning materials which might contribute to a greater retention rate in the adult learner.

Alternatively, face-to-face training is facilitated by an educator who presents the information, tests, grades, and then delivers the results to the department on behalf of the agency. Such an example can be found in the cooperative training delivered by the Mineta Transportation Institute. Using funds from the National Cooperative Highway Research Program (NCHRP), the MTI works in "conjunction with the California Department of Transportation (CalTrans) to deliver ICS training to transportation employees" in fulfillment of the federal NIMS/ICS mandate (Hambridge, Howitt, Giles, 2017, p.9). This training consists of various means of 
conveying the information to trainees which address the concept of andragogy in attempt to facilitate learner retention. These include verbal instruction, "written (physical) hand-out portions," and PowerPoint slideshows which help to "illustrate the materials" through various means to accomplish a "three-mode learning element: hear, see, read" (Edwards, Goodrich, Griffith, 2016, pp.10; 26). These face-to-face classes can also include "small-group problem solving, practical application of materials (as shown in the Appendix photos 1-7), and workshops on resource development" (Edwards, Goodrich, Griffith, 2016, p.10), which assist in trainee development of the skills necessary to fulfill the mandate.

Finally, the blended delivery option uses a mixed approach to training, relying on both the self-direction and responsibility of adult learners combined with support from a directed learning environment potentially supported by learning materials. While it supplies multiple approaches to adult learning, it might be unfeasible to execute such a program. Ultimately, andragogy, or understanding how adult learners approach the process of learning and retaining information, helps to effectively administer training to both satisfy the federal mandate and facilitate greater learner retention. 


\section{METHODOLOGY}

\section{Outcome Evaluation}

In researching the method of FEMA mandated ICS 100/200 training delivered to operation line employees at surface transit agencies, the author constructed a questionnaire that was delivered to each agency's emergency manager/coordinator, examined the rigor/reliability of the current training method (e.g. online, face-to-face, blended) through a survey of current literature, and developed a recommendation for future training delivery that considers feasibility and efficacy as the primary factors. The essential questions for this assessment are the current training delivery method employed by the agency for their operation line employees; the number of those employees that are required to receive ICS 100/200 training, and why this method has been used versus existing alternatives. Secondary questions to also be included by the author tried to provide a more complete picture of the agency's motivation for preferring one training method over another, what they would change if they could, and the extent of the emergency manager's/coordinator's experience with ICS deployment in the field.

Benchmarking is necessary to assess the expected rigor/reliability for the delivery of these mandated trainings; Do specific delivery methods produce better expected outcomes than others, what are the cost differentials, how might an agency better address this mandate and serve the public and their operation line employees? Assessing the current training methodology along with the other factors mentioned helps to provide a more complete picture of the issue, and thereby deliver a more effective recommendation. 


\section{Table 2: Outcome Evaluation}

\begin{tabular}{|c|c|c|c|c|c|}
\hline PROGRAM & $\begin{array}{c}\text { THEORETICAL } \\
\text { GOAL }\end{array}$ & GOALS & $\begin{array}{c}\text { PROGRAM } \\
\text { FUNCTIONS }\end{array}$ & $\begin{array}{l}\text { PROXIMATE } \\
\text { INDICATORS }\end{array}$ & MEASURES \\
\hline $\begin{array}{l}\text { HSPD-5 } \\
\text { mandated } \\
\text { NIMS/ICS } \\
\text { 100/200 } \\
\text { training for } \\
\text { operation line } \\
\text { employees at } \\
\text { ground transit } \\
\text { agencies; } \\
\text { benchmarking } \\
\text { current } \\
\text { delivery } \\
\text { methods and } \\
\text { their efficacy }\end{array}$ & $\begin{array}{l}T_{1}: \text { Identify the } \\
\text { most productive } \\
\text { training delivery } \\
\text { method for } \\
\text { operation line } \\
\text { employees at } \\
\text { ground transit } \\
\text { agencies }\end{array}$ & $\begin{array}{l}G_{1}: \\
\text { Compliance } \\
\text { with } \\
\text { federal/FEMA } \\
\text { mandate } \\
G_{2}: \text { Increase } \\
\text { training } \\
\text { efficacy and } \\
\text { employee } \\
\text { retention } \\
G_{3}: \text { Increase } \\
\text { agency } \\
\text { emergency } \\
\text { preparedness }\end{array}$ & $\begin{array}{l}F_{1}: \text { All } \\
\text { delivery } \\
\text { methods must } \\
\text { fulfill FEMA } \\
\text { mandate }\left(G_{1}\right) \\
F_{2}: \text { Assessed } \\
\text { training } \\
\text { options } \\
\text { should be } \\
\text { compliant, } \\
\text { and provide } \\
\text { employees } \\
\text { with better } \\
\text { outcomes } \\
\left.\text { (G } G_{1} ; G_{2}\right) \\
F_{3}: \text { Assessed } \\
\text { training } \\
\text { options } \\
\text { should meet } \\
G_{1}, G_{2}, \text { and } \\
\text { meet agency } \\
\text { emergency } \\
\text { preparedness } \\
\text { needs (G) }\end{array}$ & $\begin{array}{l}I_{1}: \text { Current } \\
\text { delivery } \\
\text { method as } \\
\text { compared to } \\
\text { expected } \\
\text { outcomes for } \\
\text { other delivery } \\
\text { methods }\left(F_{1} \text {, }\right. \\
\left.F_{2}\right) \\
I_{2}: \text { Number of } \\
\text { employees } \\
(\text { operation } \\
\text { line) }\left(F_{1}, F_{2}\right) \\
I_{3}: \text { Costs of } \\
\text { training } \\
\text { delivery by } \\
\text { method } \\
I_{4}: \text { Agency } \\
\text { satisfaction } \\
\text { with current/ } \\
\text { expected } \\
\text { preparedness } \\
\left(F_{3}\right)\end{array}$ & $\begin{array}{l}M_{1}: \text { Survey of } \\
\text { current } \\
\text { training } \\
\text { delivery } \\
\text { method } \\
M_{2}: \text { Survey of } \\
\text { training } \\
\text { delivery } \\
\text { methods and } \\
\text { expected } \\
\text { reliability } \\
\text { M3: Survey of } \\
\text { emergency } \\
\text { manager/ } \\
\text { coordinator } \\
\text { satisfaction } \\
\text { with current } \\
\text { training } \\
\text { M4: Survey of } \\
\text { emergency } \\
\text { manager/ } \\
\text { coordinator } \\
\text { experience with } \\
\text { ICS/ICS field } \\
\text { deployment }\end{array}$ \\
\hline
\end{tabular}


Following the distribution of the survey to emergency managers/coordinators at the surface transit agencies included within this study, the results were organized and assessed by the author to be sorted based on the criteria in Table 2. An evaluation of the gathered data was conducted to assess as primary concerns:

- Current delivery method:

- Online-only: FEMA offers many of the ICS training programs online. This consists of the students reading through materials, which they are later tested on. The students are later informed electronically of either their success or failure, to demonstrate sufficient knowledge to be granted a certificate of completion

- Face-to-Face: Training that is conducted face-to-face is typically done under the constraints of a classroom atmosphere, wherein a certified instructor introduces the material and discusses the relevant factors of implementation. The student is then presented with a test, which is graded by the instructor, who then passes a certificate on to the student after completion

- Blended: Blended training would combine any of the elements included in both Online-only, and Face-to-Face. For example, the materials are presented by a certified instructor, and the student later takes the test in an online environment

- Current number of employees that receive ICS 100/200 under the mandate

- Agency reasoning for selecting the current delivery method (e.g. cost, ease, etc.,) 


\section{Assessed as secondary concern:}

- Other motivations for training method being used, for example funding, which has been identified as a factor by Hambridge, Howitt, and Giles in Coordination in Crises: Implementation of the National Incident Management System by Surface Transportation Agencies, where it is identified as "an impediment to sustainable implementation of NIMS" $(2017, \mathrm{p} 7)$

- Persistent regional risk factors which may pose a threat to surface transit agencies (e.g. hurricane, or flood threats to PSTA, or earthquake and wildfire threat to SCCVTA)

- How the agency might change this, if it could (e.g., offered more funds to meet mandate)

- The extent of the emergency manager/coordinator's experience with ICS/NIMS deployment

- The perceived adequacy of learner retention, and therefore the ability to employ the principles of ICS 100/200 in the event of an emergency

The evaluation of this data has included a survey of the current literature regarding the efficacy of specific delivery mediums for employee training - online only, face-to-face only, and blended - to assess the effectiveness of the current methods being employed by the respective transit agency.

\section{Questionnaire}

1. Have you ever started/initiated Incident Command System/ICS?

a. Under what circumstances?

b. What if any persistent regional threats may require utilizing ICS (e.g. hurricane, snowstorm, terrorism, etc.)? 
i. What would you estimate as the frequency of ICS use in such cases?

2. Have you ever participated in Incident Command System/ICS?

a. Under what circumstances?

3. How many current operation line employees fall under the federal Incident Command System/ICS 100/200 mandate?

4. How does your agency/organization currently satisfy the ICS 100/200 training mandate for operation line employees? (Online-only, Face-to-Face, Blended)

a. Why has your agency chosen to use this training method to satisfy the mandate?

b. How does this training method benefit your organization/agency?

c. How would you rate the effectiveness of this training method?

\begin{tabular}{|c|c|c|c|c|}
\hline $\mathbf{1}$ & $\mathbf{2}$ & $\mathbf{3}$ & $\mathbf{4}$ & $\mathbf{5}$ \\
\hline Needs Substantial Improvement & Insufficient & Adequate & Good & Excellent \\
\hline
\end{tabular}

5. If granted more resources, how might your agency improve their current ICS 100/200 training delivery method (if at all)? Please be as detailed as possible.

6. Are you aware of the Transportation Resource Board (TRB) training package which includes using manipulatives to assist with training?

a. What are your thoughts regarding this training package?

Upon completion of the evaluation, several recommendations have been suggested by the author based on the data collected and reviewed, inclusive of the expected academic rigor and reported preference of the different approaches to delivering training to operation line employees at transit agencies. These recommendations have considered the effectiveness of the current delivery method in use by the respective agency in accordance with the current literature, in addition to 
considering how the agency rates the efficacy of the current training. Finally, a recommendation was made regarding what, if any, methods the agency might employ to more effectively ensure the responsive capacity of their operation line employees in the event of an emergency or incident. 


\section{LITERATURE REVIEW}

\section{NIMS/ICS}

In examining the delivery of mandated federal training of NIMS for transportation agencies it is essential to understand the history, background, and scope of the NIMS mandate, and the current delivery of Incident Command System/ICS training for operation line employees. In response to the aftermath of the September $11^{\text {th }}$ terror attacks, the administration of President George W. Bush produced Homeland Security Directive-5/HSPD-5 (Bush, 2003). HSPD-5 mandated that all public agencies wishing to remain eligible for federal disaster preparedness assistance funds must use the National Incident Management System/NIMS to manage the event (Edwards, 2016).

The development of NIMS as a universal incident management system is discussed by J.F. Annelli in The National Incident Management System: a multiagency approach to emergency response in the United States of America (2006). There are many objectives within the NIMS framework, and as such a breakdown of those items, specifically those which apply to the transportation employees receiving ICS training, is essential to producing a full working diagram of the process. The twenty-eight NIMS implementation objectives, inclusive of ICS 100 and 200, are clearly enumerated in the NIMS Implementation Activity Schedule (2017). NIMS has been the mandated framework for managing incidents for surface transportation agencies for over a decade, and whether these agencies have developed "the capabilities necessary to fit effectively into NIMS" is reviewed in Coordination in Crises (Hambridge, Howitt, Giles, 2017, p.9). 
Specific knowledge of how to improve emergency preparedness methodologies is essential to employees in leadership roles, and suggestions are made and discussed as a practical means to increase response efficacy by Edwards, and Goodrich, in the Exercise Handbook: What Transportation Security and Emergency Preparedness Leaders Need to Know to Improve Emergency Preparedness (2014). Because of the challenges posed in training operation line employees, it is necessary to assess how this information is disseminated among employees. Information regarding the type and quality of training delivery methods targeting transportation agency staff, specifically designed for adult learners, is presented by Edwards, Goodrich and Griffith in Emergency Management Training for Transportation Agencies (2016). This is important to include due to the nature of training required for operation line employees in the transportation sector. Further information about how to train operation line employees in ICS and how it might be best conducted is found in "Incident Command System (ICS) Training for Field-Level Supervisors and Staff" (Edwards, Goodrich, Griffith, 2015). Finally, the ability to improve the response that transportation agencies have post disaster is discussed by Okasaki (2003), largely as a means of improved tactics.

The history of emergency management was discussed by author/editor Claire B. Rubin in Emergency Management: The American Experience 1900-2010. The book covers the evolution of emergency management in the United States from its nascent stages to a fully developed federal concept by 2010. Specific attention is paid to how disasters can be viewed as "focusing events" (Butler, 2012, p.14), and how these events - 9/11 is a strong example - have served to focus national attention on the need for a robust emergency management system - which the authors contend is the responsibility of the government to provide (Harrald, 2012, p.170). Additionally, Emergency Management: The American Experience defines the timeline for post- 
9/11 emergency management measures, such the National Response Plan (NRP), and NIMS, which supply essential background for understanding the evolution of the current system in place (Harrald, 2012, pp.173-178). Finally, the authors take time to define what they describe as the "critical flaws" that remain within the emergency management framework, and how they might be addressed to be better prepared for the next event (Roberts, Ward, Wamsley, 2012, pp.247276). Ultimately, Emergency Management: The American Experience clarifies the history of emergency management, where it is going, and how it might be shaped for the better.

\section{Living with Hazards, Dealing with Disasters: An Introduction to Emergency}

Management (2000) delves further into the history of emergency management. Author William L. Waugh employs a critical, case-study approach to describe emergency events, organizations, and policy issues to build a professional examination of emergency management. In chapter 2, Waugh discusses “Obstacles to Effective Emergency Management," which defines some of the problems faced by emergency management agencies when they attempt to focus support on their efforts and needs (Waugh, 2000). There is a notable alignment with some of the critiques mentioned by authors in Rubin (2012), which are strongly mirrored by Waugh. Specifically, Waugh describes the lack of attention directed towards emergency management agencies outside of disasters, which results in the agencies playing catch-up, and often being ill-prepared to immediately address a given incident (Waugh, 2000). This is largely due to an out-of-sight, outof-mind effect, in that there is only a strong focus on disasters and emergency management directly after a disaster or emergency has occurred; the public, and therefore the policymakers, are more attentive. In addition to these background issues, Waugh dissects several different emergency events ranging from natural hazards to manmade disasters, which effectively convey the diversity of threats that emergency agencies are tasked with addressing (Waugh, 2000). The 
focus on events, combined with an effective description of barriers to effective disaster management, serve to provide an insight into the broader issues faced in emergency management, which help to widen the focus on emergency management research, while providing critical insight into the events themselves.

In Disasters by Design: A Reassessment of Natural Hazards in the United States (2004), author Dennis S. Mileti examines the deep roots of disaster management and mitigation and the contributors to the field which originate from a wide range of professional disciplines. The framework on which these professionals have built a comprehensive approach has been designed to "enhance society's ability to reduce the costs of disaster" within communities and across the nation (Mileti, 2004, p.1). In addressing the multifaceted roots of the problem, the author recognizes how a lack of sustainability in the proliferation of manmade improvements have altered the natural landscape and have "destroyed local ecosystems that could have provided protection from natural perils" (Mileti, 2004, p.3). Mileti notes that the cost of the impact of disasters has increased due to unsustainable management principles. The author places the dollar value of these hazards "conservatively, $\$ 500$ billion, or about $\$ 0.5$ billion per week" during the period ranging "from 1975 to 1994" (Mileti, 2004, p.66). Of prime interest to this research, Mileti suggests that a "nationwide risk assessment, including education" is essential to building the ability to address critical concerns (Mileti, 2004, p.13), while simultaneously relying on inter-community and organizational networks which would help to integrate the disaster response agencies (Mileti, 2004, pp.269-270). Further, in calling for better education and training, the author posits that the development of "collaborative research efforts" which rely on "standardization of instrumentation, data processing, documentation, and analytical approaches" will provide a solid foundation for future efforts towards sustainable disaster management 
(Mileti, 2004, pp.277-278). Finally, according to Mileti, the training that the federal government has begun to standardize should both continue and be expanded to address more than just the traditional fields associated with disaster management (Mileti, 2004, p.278). Disasters by Design assisted in providing both background and the structural importance for sustainable disaster management, as well as the continued proliferation of effective training for persons involved in response to critical emergencies.

Managing Crises: Responses to Large-Scale Emergencies by authors Arnold M. Howitt and Herman B. Leonard, is written to frame multiple disasters of both natural and manmade origin from start to finish, and provide an in-depth post-mortem of what happened, what worked, and what did not work. The authors' early comment on "preparedness and response capacity" indicates that both the public and elected officials focus on emergency management when "highly visible events are handled poorly", raising concerns about response and preparedness (Howitt, Leonard, 2009, p.3). These sentiments have been voiced by many in disaster management, and speak to the out-of-sight, out-of-mind aspect to emergent threats; unseen or unanticipated threats are often forgotten about by the public until they are well into the disaster timeline.

Of primary importance to the research for this document was the focus on the 9/11 attack on the Pentagon in Washington, D.C., and how the event demonstrated the importance of ICS in emergency response efforts in limiting damages and loss to human life (Howitt, Leonard, pp.238-249). The section covers the origins of ICS in southern California, and references Dana Cole in stating that ICS has become "the world's leading management system for command, control and coordination of emergency scenes" (Howitt, Leonard, 2009, p.241). The chapter then deconstructs the event from the point of impact to the response capacity that was provided 
by the Incident Command System structure, citing a post-event assessment commissioned by Arlington County, VA. in stating that the "state of preparedness was very high" and "there were no fatalities or serious injuries among first responders" (Howitt, Leonard, 2009, p.268). Further, "individuals from different organizations were able to work together effectively" in an "ad hoc" team structure which was due in large part to the use of ICS in responding to the event (Howitt, Leonard, 2009, p.268). The deconstruction of this event by Howitt and Leonard effectively demonstrates the strength of the Incident Command System in disaster response, and in doing so it provides ample justification for its continued use in disaster response/emergency management.

In Waugh and Kathleen Tierney's edited volume Emergency Management: Principles and Practice for Local Government (2007), various authors discuss the impact of disasters on local governments, and how new innovations, technologies, and cooperation have affected emergency management. In the section entitled Major Issues in Emergency Management: Legal Issues, William Nicholson covers the laws that govern funding of emergency management obligations, such as training and exercises. This section supplies information on the HSPD-5 mandate [established NIMS] which stated that "state and local agencies that failed to comply" with the mandate, would "lose eligibility for federal grants and other funding" (Nicholson, 2007, p.239). Additionally, the text clearly outlines the agencies which fall under the HSPD-5 mandate, as well as stating that NIMS established "the guidelines, protocols, and standards" for “personnel training and exercises," and "qualification and certification" of staff and employees falling under the scope of the mandate (Nicholson, 2007, p.239). This includes operation line employees at surface transit agencies, who are required to complete training in ICS 100/200. The goal of establishing these requirements is to ensure that there is a basic compliance in capacity, and function in emergency responders. Emergency Management (2007) provides a 
local government perspective of the impact of NIMS, and therefore ICS mandates on local governments.

Disaster Policy and Politics: Emergency Management and Homeland Security by

Richard Sylves broadly discerns the issues in emergency management. The author covers HSPD-5, and the National Response Framework/National Response Plan [NRP] and how this impacts state and local agencies (Sylves, 2015, p.170). The NRP was intended to represent a “single, comprehensive national approach" to emergency management, which was intended to "harmonize intergovernmental and interagency incident management" (Sylves, 2015, p.171). This reflects the intent of HSPD-5 and NIMS as described by Howitt and Leonard (2009), and Nicholson (2007), a system that unifies training preparedness, capacity, and response.

Additionally, Sylves states that local emergency managers are "expected to learn the ICS framework, participate in ICS exercises" as well as "acquire the requisite certifications" (Sylves, 2015, p.173). The text describes the FEMA Emergency Support Functions (ESFs) and Emergency Support Function Coordinators, with transportation designated as "ESF \#1," and the ESF \#1 Coordinator as the Department of Transportation (Sylves, 2015, p.172). Ultimately, the author contributes to the understanding of the federal directives/mandates which impact surface transit agencies, such as HSPD-5, NIMS, and finally ICS 100/200.

\section{Training Methods and Modes}

It is important to the scope of this research to ascertain what training delivery methods might produce higher retention of the information, and greater employee satisfaction with training. Further, information regarding the efficacy of different training, or teaching delivery modes was gathered; specifically, examination of online, blended, and face-to-face delivery modes and how this affects retention and outcomes. A meta-analysis of this research was conducted by Means, 
Toyama, Murphy, and Bakie (2013). The outcomes and learning satisfaction differences between online and blended delivery approaches is examined in "Online Vs. Blended Learning: Differences in instructor outcomes and learner satisfaction” (Lim, Morris, Kupritz, 2014). Elearning processes can enhance learning opportunities for employees and might contribute to a better prepared workforce (Clarke, Lewis, Cole and Ringrose, 2012). Because employee satisfaction with the learning process can prove integral to retention, the relationship between workplace training and overall job satisfaction is examined by Schmidt (2007). Schmidt specifically examines training methodologies, overall time spent in training, and content in determining what constitutes contentment with training, and thereby affects employee satisfaction (Schmidt, 2007). Research also indicates that students with different learning styles prefer different delivery modes for information, with specific typologies selecting online versus print, however, a numerical majority prefers classroom-based learning (Buch, 2002). More information needs to be gathered regarding how employee satisfaction might have related to job performance, and how training modes might fit into the overall picture of information retention for employees.

\section{In Self-directed Learning: Implications and Limitations for Undergraduate Nursing}

Education, author Tracy Levett-Jones addresses the results of instructor lead education versus Self-Directed Learning (SDL). While the cohort in question differs from the one being researched in this document, the research into the limitations and implications of self-directed learning play a role in understanding the training delivery methods commonly used in ICS 100/200 training. Author Levitt-Jones states that "didactic instruction" regarding SDL is necessary to help students to completely understand the processes behind SDL (Levett-Jones, 2005, p.4), and that "successful introduction of SDL" "requires adequate student preparation" 
(Levett-Jones, 2005, p.4). Ultimately, the author asserts that there remains a responsibility from the teachers to the learners - in this regard it is essential that the students understand what is expected of them from the training that is being administered. The ability to demonstrate competency with ICS 100/200 is essential to the effective execution of duties expected of operation line employees, and therefore an understanding of both the teacher's, and learner's responsibilities is of prime concern during the training process.

Finally, adults learn differently than children, yet most adult training is modeled on pedagogy principles. Therefore, the core concepts involved in andragogy were explored to determine the best approach for delivering training to employees that fall under the federal mandate. In Andragogy: Origins, Developments and Trends, author Serguey Zmeyov addresses aspects of andragogy and provides valuable insight into the best methods for the education of adult learners (Zmeyov, 1998). The author discusses aspects of adult learners which differentiate them from younger learners, such as their being "self-directed, and responsible" (Zmeyov, 1998, p.4), as well as offering an effective definition of the term andragogy. This provides an understanding of the way adults learn based on specific aspects of their mannerisms, inclusive of their experiences and skill-set, and supplies a foundational definition of andragogy that helps to determine how to best present training information to adult learners in a professional setting.

\section{Information from Transit Agencies}

The size and service areas of the Santa Clara County Valley Transit Authority/SCC VTA, South Eastern Pennsylvania Transportation Authority/SEPTA, Delaware River Port Authority/DRPA, and Pinellas Suncoast Transit Authority/PSTA can be found via agency sources online, and primarily through communication through the questionnaire. 
Information gathered has included the following:

- Current number of operation employees mandated to receive ICS 100, and ICS 200 training

- The delivery methods for that training: online solely; blended; face-to-face.

- The agency's experience with deploying ICS to address incidents (or in practice/training), if at all, and the length of ICS use if it was used

- Identification of any persistent regional threats that the surface transit agency might encounter while performing its duties.

- How the agency rates the effectiveness of their current training methodology,

- Their experience with the TRB training packet with manipulatives which was created by Dan Goodrich and Frances Edwards.

As indicated, this information was gathered by the questionnaire provided to emergency managers within the specific agencies that were being researched. If further information was required it was accessed from online sources, or direct communication with the emergency managers/staff from the respective agencies.

\section{FINDINGS}

The results of the questionnaire were collected both in person and through personal correspondence (via email and telephone), based on the availability of the subject being interviewed. The data was derived from the answers supplied in the questionnaire, which was designed to assess how the surface transit agencies included in the sample currently deliver ICS 100/200 training to their operation line employees, and their familiarity with training materials. In cases where the answers were incomplete or unclear, further contact was initiated to ensure 
mutual understanding of answers given in completing the questionnaire to eliminate any lingering ambiguity.

The questionnaire consisted of six questions and sub-questions which are designed to ascertain the respondent's familiarity with ICS as a participant or initiate [2], the regional/persistent threats that their agency might face [sub], frequency of ICS use [sub], employees which fall under the federal training mandate [1], questions about current training methodologies [1], a Likert scale question [1], and a question regarding the agency's familiarity with the TRB training packet [1] as well as its utility [sub]. The questions are displayed in a table which lists all responses, the responses having been summarized below both for brevity and clarity of message. 


\begin{tabular}{|c|c|c|c|c|}
\hline Table 3 & SEPTA & DRPA & PSTA & SCCVTA \\
\hline Q.1 ${ }^{1}$ & Yes & Yes & $Y e s$ & Yes \\
\hline Q.1a & $\begin{array}{l}\text { During major and minor } \\
\text { incidents that affect employees, } \\
\text { facilities, passengers, and the } \\
\text { public }\end{array}$ & $\begin{array}{l}\text { During multiple incidents; } \\
\text { sporting events, natural } \\
\text { disasters, political events }\end{array}$ & $\begin{array}{l}\text { Primarily hurricanes and } \\
\text { evacuations }\end{array}$ & $\begin{array}{l}\text { Managing all bus/light } \\
\text { rail/construction accidents or } \\
\text { incidents as the IC for VTA }\end{array}$ \\
\hline Q.1b & $\begin{array}{l}\text { Snowstorms, ice storms, severe } \\
\text { weather and terrorism }\end{array}$ & $\begin{array}{l}\text { Range of incidents }- \text { e.g. } \\
\text { storms }\end{array}$ & $\begin{array}{l}\text { Hurricanes, strong storms, } \\
\text { evacuations, large events }\end{array}$ & $\begin{array}{l}\text { Earthquakes, floods/storms, } \\
\text { large events }\end{array}$ \\
\hline Q.1i & $\begin{array}{l}\text { Minor incidents do not require } \\
\text { full ICS deployment, rather a } \\
\text { single IC and small unit clear } \\
\text { the incident }\end{array}$ & $\begin{array}{l}\text { ICS is utilized in every } \\
\text { event/incident }\end{array}$ & Two/three times per year & $\begin{array}{l}\text { ICS used in all events, large or } \\
\text { small }\end{array}$ \\
\hline Q.2 & Yes & Yes & Yes & Yes \\
\hline Q.2a & $\begin{array}{l}\text { All incidents that require } \\
\text { major response }\end{array}$ & $\begin{array}{l}\text { Both with incidents and } \\
\text { training }\end{array}$ & $\begin{array}{l}\text { Hurricanes/evacuations/worki } \\
n g \text { with county EOC }\end{array}$ & $\begin{array}{l}\text { As VTA IC and part of Joint } \\
\text { Command }\end{array}$ \\
\hline Q.3 & 9200 operation line personnel & 200-250 active & $\begin{array}{l}\text { Everyone; } 5 \text { ICS center } 5 \\
\text { persons }\end{array}$ & $\begin{array}{l}\text { All frontline/operation line } \\
\text { employees }\end{array}$ \\
\hline $\mathbf{Q . 4}$ & Face-to-face & Blended & Face-to-face & Face-to-face \\
\hline Q.4a & $\begin{array}{l}\text { New hires; done with } \\
\text { orientation }\end{array}$ & Due to critical nature of jobs & $\begin{array}{l}\text { Interaction allows for greater } \\
\text { learner retention }\end{array}$ & $\begin{array}{l}\text { To facilitate well } \\
\text { trained/prepared employees }\end{array}$ \\
\hline Q.4b & $\begin{array}{l}\text { Immediate feedback; better } \\
\text { understanding of curriculum }\end{array}$ & $\begin{array}{l}\text { Self-paced, and feedback- } \\
\text { based learning; deeper } \\
\text { understanding }\end{array}$ & Feedback & $\begin{array}{l}\text { Allows VTA to work seamlessly } \\
\text { with other jurisdictions }\end{array}$ \\
\hline Q.4C & Good & Excellent & Good & Good \\
\hline Q.5 & Add online training & Sustain current method & Add outside personnel/experts & Add online training \\
\hline Q.6 & Not before presented & $\mathrm{No}$ & Not before presented & Yes \\
\hline Q.6a & $\begin{array}{l}\text { Useful for in-field personnel } \\
\text { compliment training }\end{array}$ & - & Assist in event of incident & $\begin{array}{l}\text { Helpful for operation line } \\
\text { employees }\end{array}$ \\
\hline
\end{tabular}

1 Q.1, .1a, .1b, etc., refer to questions supplied to transit agencies with the questionnaire; complete question verbiage is available in the "Questionnaire" section of this document. 


\section{ANALYSIS}

The results of the questionnaire that was disseminated among the interviewed personnel offered a glimpse into the manner in which training is currently delivered at surface transit agencies from different regions of the United States. There is an observable similarity among those surveyed regarding the experience in the initiation of ICS, either in the case of an incident, or through the course of training (Q.1, Q.1a). This suggests that the persons surveyed have reasonably deep experience with ICS as an active tool used to respond to events across the service areas under the purview of the agencies included in this benchmarking. Admittedly, this depth of experience was both unexpected and welcome, as it is indicative of emergency managers who are familiar with their roles and responsibilities at transit agencies and experienced with the tools they are charged with using.

The questions further demonstrated the surveyed recognition of persistent regional threats - earthquakes, hurricanes, etc., - which exist as a result of geography, climate, and population/demographics (Q.1b). Additionally, the respondents highlighted the use of ICS in working major planned events to execute an effective command of the areas under their control. These questions and responses show that the persons working in these regional transit agencies those in the upper echelons of the agencies - are well trained, and aware of the threats that they face in their position as emergency managers, which aligns with transit agencies as essential to emergency response (Hambridge, Howitt, Giles, 2017, p.7-8). This has also helped to demonstrate that these actors have a well-developed understanding of the expectations outlined in the mandate disseminated by FEMA (Department of Homeland Security, 2012, pp.3-4), which builds a profile of a culture within these surface transit agencies suggestive of dedication to the ICS system and its core precepts. 
Regarding the frequency of ICS deployment in the case of incidents and emergencies, all respondents indicated that ICS is used in events large and small, for both persistent regional threats, and in the case of unexpected occurrences as well (Q.1i). This follows the dictums of the ICS mandate, and ensures that responsible parties at surface transit agencies are well practiced in using ICS to manage all incidents, large and small, to a high degree of efficacy, and conforms to the intent of the ICS mandate as enumerated in HSPD-5 (Bush, 2003). Further, all emergency managers answered that they have participated in ICS, either in responding to an incident, or through a practice exercise. Once again there is a marked alignment in understanding of the utility of ICS deployment for large and small events, ranging from a single person to countywide incident (Q.2, Q.2a). Considering the preparedness of the respondents, there is seemingly a deep commitment to the principles and necessity of ICS as a means of managing emergency events.

In response to the number of current operation line employees that fall under the federal mandate, there was a wide degree of variance in the supplied answer, with some agencies electing to include a numerical value, and others addressing the question from a perspective which employees fall under the mandate (Q.3). As a result, responses range from 9,200 employees that fall under the mandate to a simple recognition of frontline (operation line) employees who fit the requirement. When asked about how their respective agency delivers the mandated training to the aforementioned employees, the most common response was face-toface (3), followed by a single response indicating the use of a blended training option (1) (Q.4). The use of the face-to-face training method might be indicative of an understanding of this method's effectiveness as noted by Zmeyov due to learner engagement (1998), as well as Edwards, Goodrich, Griffith (2016). Alternatively, the blended option in use by the DRPA might represent a more time/resource consuming process for the employee (though perhaps 
meaningful) and may be beyond the tolerances felt at the other responding agencies. It is noteworthy that all agencies voice similar sentiments about why they had chosen to use their respective training method, the method's efficacy (Q.4a; Q.4b), and that none had selected an online only option for ICS 100/200 training. Importantly, while the online only option/SDL does offer some of the responsibility that adult learners are drawn to (Zmeyov, 1998), it comes with the added caveat that it requires "adequate student preparation" or in other words necessitates greater involvement/investment of time than an agency might initially assume based on the basic characteristics of SDL (Levett-Jones, 2005, p.4). All respondents point to the critical nature of their preparedness as a reason for having a well-trained cadre of operation line employees and suggest a broad support for the training method employed by the agency. A recognition of the importance of this training, from both a perspective of the mandate, and from the view of the dire importance of the duties required of transit employees, provides an essential insight into the sense of duty felt by these agencies.

When asked to rate the effectiveness of their current training method, the agencies were given a list of possible responses with a numerical value on a Likert scale ranging from 1, or needs substantial improvement, to 5, or excellent. Most respondents indicated that their current training method was 4, or good, which suggests an overall satisfaction with the training currently in use by the agency $(\underline{\mathrm{Q} .4 \mathrm{c}})$. This might also imply that there is some room for improvement, which was expected, however, the recognition of this fact by the emergency coordinators/managers is commendable. One agency did state that their training method was 5, or excellent $(\underline{\mathrm{Q} .4 \mathrm{c}})$, and it is perhaps noteworthy that this agency also uses a blended training delivery method to its employees (Q.4). A blended training option is perhaps preferable, at least to an online-only teaching method, and this is supported by Lim, Morris, and Kupritz (2014), 
where they found that while there was no significant difference in the "perceived learning" of the student after the lesson ( p.34), the students simultaneously reported a sense of more support, and clearer understanding of what is expected of them from the addition of instructor interaction ( $\mathrm{p}$. 35). Of course, this adds little to the comparison here between a blended and face-to-face approach to satisfy the mandate, which is observed in the above results. However, this difference is perhaps better elucidated by examining how the agencies who rated their method as good versus excellent might improve their current method. Two of the responding agencies SEPTA and SCCVTA - both suggest that the addition of an online program in conjunction with their face-to-face format might help with delivering training to operation line employees (Q.5). In addition to an interest in "blending" their current training methods, two agencies also stated that holding exercises or drills might help with learner retention and preparedness (Q.5). While this is anecdotal and self-reported in the questionnaire supplied to these agencies, it is experientially supported by Edwards, Goodrich, Griffith, where they employed real-world scenarios in their training exercises to better involve the trainees in the learning process (2016, p.21). An addition of an SDL or online component might allow for more flexibility and the ability to drill on the requirements of ICS - again accompanied by a face-to-face element.

Finally, the questionnaire asks about the emergency manager's experience with the TRB packet that includes manipulatives and may also serve as a field deployable asset for operation line employees (Q.6). A single agency, SCCVTA, had familiarity with the packet prior to being presented with it during the interview. In answering the follow-up question, SCCVTA further indicated that the TRB packet might prove "helpful to operation line employees actively involved in emergency incidents" (Q.6a). Similarly, both SEPTA and PSTA suggested that the packet could aid employees responding to emergencies. One agency, DRPA, did not receive the 
packet as the interview was conducted remotely, therefore in the table they have been assigned a null entry in this category (Q.6a). The appreciation of the TRB packet suggests that it might serve a purpose in assisting in-field/operation line employees in their day-to-day jobs as well as training. Such an asset has not been previously deployed successfully, and the lack of familiarity with the packet is something that might be dealt with through greater promotion through TRB's professional contacts, such as the American Academy of State Highway and Transportation Officials (AASHTO).

Overall, the emergency managers at the agencies included in the questionnaire demonstrated a high-level commitment to the federal mandate for ICS 100/200 training. They all expressed a great regard for the process, as well as displayed a great deal of preparedness and practice with the methods they are required to engage in the event of an emergency incident. This is at least suggestive of a strong culture of appreciation for the NIMS/ICS system, and a deep understanding of its importance down to the operation line-employee level. They expressed an understanding of persistent regional threats that their respective agency faces, and an understanding of the necessity to employ ICS in meeting these threats. While the most common training method in use was the face-to-face option (3) [a single agency electing to use a blended approach], those same three agencies also suggested that (if granted more resources) an addition of an online element would assist in the training process; thereby creating a blended methodology. When asked about their familiarity with the TRB packet, two had no previous knowledge of the packet, one had seen it prior to receiving the questionnaire, and one was assigned a null value due to a lack of a physical opportunity to examine the packet. However, when the two agencies who had no previous experience with the packet examined it, they suggested that it might assist operation line employees in training and performing their jobs. 


\section{Limitations}

While the research achieved its goals and was carefully prepared to adhere to strict academic standards, there are limitations and shortcomings that were deemed unavoidable due to several factors. First, the research was limited to only four regional (2x Northeast, 1x Southeast, and 1x West) surface transit agencies: SEPTA, DRPA, PSTA, and SCCVTA, respectively. While the agencies were selected to represent the training delivery methods (ICS 100/200 operation line employees) from similarly sized population service areas in different regions of the country, they are by no means a complete survey of transit agencies operating within the United States. Because of time and opportunity constraints, this research does not include sufficient numbers of surface transit agencies to produce a statistically significant estimate of how the federally mandated training is delivered nationally, and therefore the results only represent a fraction of the extant field. It is recommended that any future assessment should attempt to ascertain the training methods employed at more transit agencies across the U.S. to provide a more complete picture of the current training procedures employed to meet the federally mandated ICS 100/200 training of operation line employees across the country.

Second, the questionnaire which was delivered to representatives of the transit agencies included in this study relied largely on self-reported information. Again, due to time and opportunity constraints, there was not a capacity to observe the actual delivery of the requisite training to operation line employees or circulate the questionnaire directly within this group and await a complete response. Future research should consider either direct observation of training or circulate surveys/questionnaires among the employees in question to build a more complete understanding of the training methodologies employed at surface transit agencies (pre-test/posttest). Additionally, because the questionnaire asks the representatives about their assessment of 
the training methods they currently employ to satisfy the federal mandate on ICS training, there is a potentially subjective nature to these responses. As such, the responses to these qualitative questions might also be formed while the respondent is considering agency priorities or limitations (fiscal, or otherwise) and thereby might not be independent of prejudice. Further, the author of this paper has some experience with the TRB training materials referred to in the questionnaire - both in a training capacity and in the preparation of video supplements regarding the proper deployment and use of the TRB packet. Additionally, one transit agency did not have an opportunity to examine the packet, as all communication was conducted remotely. In this case the agency was given a null entry in the returned questionnaire for this section (Q.6); bringing a total agency response of three, which while helpful is not, as previously mentioned, a statistically significant measure of exposure to the TRB packet.

Finally, the author of this study worked as an assistant and intern who assisted in delivering training to employees at the Santa Clara County Valley Transit Authority, or SCCVTA. While every attempt was made to remain independent and unbiased, this is a fair disclosure regarding experience with an agency included in the above study. A complete survey of extant surface transit agencies would offer a full picture of the current training methodologies employed and would help to build a more comprehensive set of options through which the training of operation line employees might be better satisfied. 


\section{Recommendations}

The recommendations will consist of two basic appeals, one regarding the further research of the nation's surface transit agencies, and the other involves a way to improve training and preparedness now. The call for more research into the delivery of ICS 100/200 training to operation line employees at surface transit agencies would seek to improve both the training process, and trainee retention of vital information, but first provide a more complete picture of the training methods currently employed. Secondly, it would seek to elucidate if there is a national pattern of preference for a blended option in satisfying the federal mandate. Finally, there should be a more complete assessment of what factors might impede training improvements at surface transit agencies, e.g. federal funds, logistical issues/framework or related deficits. Additionally, there is a suggestion of other material methods that might assist in the process, such as the TRB/ICS packet. The packet has been described, and there has been a firm accounting of its field applicability as well as its use, both in training, and in active incident response.

The overall picture provided by the information gleaned from the questionnaire is one of both understanding and a full embrace of the ICS/NIMS mandate by the surface transit agencies surveyed. Most of the agencies use a face-to-face method for satisfying the federal mandate with a single agency using the blended method; all surveyed agencies refrained from an online only training method. The agencies reported a high degree of satisfaction with the training methods they currently use, ranging from good to excellent, which implies that they are actively achieving their goals and satisfying the mandate. However, as indicated above, when asked how they might improve their current ICS 100/200 training method, two agencies suggested the inclusion of an online component, which would create a de facto blended approach. This demonstrates that 
these agencies feel this method might better assist with training; a single agency already employed this approach - they alone rated their training method as excellent. While the current methods use the concepts that have been identified by both Zmeyov (1998), and Edwards, Goodrich, Griffith (2016) as being essential to andragogy, the self-reported regard for the addition of an online or SDL component by two agencies warrants a more comprehensive survey of the nation's surface transit agencies to determine the fit of such an application. Further studies should focus on discerning why agencies might elect to employ additional online, or SDL, portions to their current training methods, e.g. how they feel these methods might qualitatively improve retention or use of the information included in ICS 100/200 training. This might be accomplished by a longer, more intensive survey which focuses on questions specifically targeting training types and delving into agency perceptions regarding practices focused on training improvement. Admittedly, this would require a more substantial investment of time and energies but would provide a more complete benchmarking of ICS 100/200 training delivery at surface transit agencies.

In addition to this, it is recommended that surface transit agencies consider the use of the TRB packet in both training and in the field as a deployable asset. The TRB packet is highly modular and includes manipulatives which would assist in the training process as it allows trainees to visually inspect the individual components of NIMS/ICS (ICS 100/200 inclusive), as well as familiarize themselves with the corresponding forms (Q.6). Items within the kit include directions and checklists for each section's role in the ICS process, which are laminated to make them resilient and capable of being handled many times before they need to be replaced. ICS forms are included which can be examined and filled out as necessary, as well as sleeves to protect and display them. The FIRESCOPE Field Operations Guide provides a complete 
breakdown of ICS. Three legal pads and pens for notes and forms are included, and it is all enclosed in a compact kit that can accompany employees into the field or be used in the classroom (Table 4). Visuals of the packet elements are in Appendices $1-7$.

Further, at this point in its development, the TRB packet has a large amount of supporting information and materials that would assist in remote-site packet creation, training-oriented-use, and field deployment, including videos describing how to build the packet from scratch and use it in an incident and training. In training the TRB packet can be used to accentuate the learning of ICS $100 / 200$ by providing materials which can be held and manipulated by the learner while they undergo the mandated training in a convenient setting. The importance of physical and visual aids in adult learning was discussed by Edwards, Goodrich, Griffith when they noted the use of similar items in their own review of andragogy and learner retention (2016). Also, as previously mentioned, the kit lends itself well to modification, thereby suiting local needs and allowing for a wide degree of applicability, including growing or contracting to fit agency needs for different documentation. The ability to include these items in training helps to inculcate a greater understanding of the ICS materials, and might also lead to a more effective field response.

The TRB kit itself is light, mobile, and well suited to being carried alongside employees in buses, light-rail, and trains for easy field deployment by operation line personnel. The ability to train with elements that are also field deployable may provide an advantage over training alone and serves as a checklist in emergency situations when clarity of intent and mission is essential to resolving incidents safely, and expeditiously. The TRB kit offers a great deal to enhanced traditional training methods, from online only, to blended options, and enriches the learning experience for operation line employees. It is recommended that surface transit 
agencies explore the current TRB packet design and available materials, which are available at no cost through the TRB website at http://www.trb.org/Main/Blurbs/173984.aspx. This site includes Word versions of all kit components for easy customization. Agencies can consider adding it to their own training regimen as an accessible accompaniment to current training practices. 
Table 4: Current ICS/TRB Kit Contents ${ }^{2}$

\begin{tabular}{|c|c|c|}
\hline & Purpose & Quantity \\
\hline Incident Commander (IC) Card & $\begin{array}{l}\text { Ensure safety of personnel, notify Operations } \\
\text { Control Center/OCC or EOC and organize event; } \\
\text { includes checklist }\end{array}$ & 1 \\
\hline Safety Officer Card & $\begin{array}{l}\text { Ensure personnel are safely conducting } \\
\text { themselves, and dangerous situations/areas are } \\
\text { avoided; answers only to IC-includes checklist }\end{array}$ & 1 \\
\hline Planning Chief Card & $\begin{array}{l}\text { Collect, organize and present information } \\
\text { concerning the event and actions taken in } \\
\text { responding to it; includes checklist }\end{array}$ & 1 \\
\hline Logistics Chief Card & $\begin{array}{l}\text { Inventory supplies. Identify items need to support } \\
\text { and enable continued field response; includes } \\
\text { checklist }\end{array}$ & 1 \\
\hline Incident Action Plan Card & $\begin{array}{l}\text { After Logistics and Safety Officer have assessed } \\
\text { their areas, report to IC; initiate Incident Action } \\
\text { Plan (IAP) - includes checklist }\end{array}$ & 1 \\
\hline Transfer of Command Card & $\begin{array}{l}\text { Instructions about conducting an effective transfer } \\
\text { of command, e.g. face-to-face; includes checklist }\end{array}$ & 1 \\
\hline $\begin{array}{l}\text { Joining an Existing Incident } \\
\text { Command Card }\end{array}$ & $\begin{array}{l}\text { Instructions regarding the proper procedure for } \\
\text { joining an existing Incident Command; includes } \\
\text { checklist }\end{array}$ & 1 \\
\hline Legal Pad & $\begin{array}{l}\text { Included to provide necessary writing space for } \\
\text { notes }\end{array}$ & 3 \\
\hline Writing Instrument (Pen) & $\begin{array}{l}\text { Ensures a supply of writing instruments to fill out } \\
\text { ICS paperwork and take notes }\end{array}$ & 3 \\
\hline $\begin{array}{l}\text { FIRESCOPE Field Operations } \\
\text { Guide }\end{array}$ & $\begin{array}{l}\text { A full accounting of proper ICS rules and } \\
\text { procedures and the proper completion of forms }\end{array}$ & 1 \\
\hline ICS documents and Forms & $\begin{array}{l}\text { Physical copies of specific ICS paperwork which } \\
\text { would be filled out in responding to an incident }\end{array}$ & - \\
\hline ICS Kit/Packet (Case) & Encloses all materials; lightweight and mobile & 1 \\
\hline
\end{tabular}

2 This is an accounting of the materials contained in the TRB ICS training/field kit, images of which are available in the appendices 


\section{CONCLUSION}

Preparedness for threats to the nation's infrastructure is critically important, and the evolution of preparedness at surface transit agencies has wound a jagged course through recent history; growing in bursts as crises changed and evolved. From its origins in responding to the southern California wildfires to the terror attacks of 9/11, hurricane Katrina, and beyond, NIMS/ICS has evolved from a regional tool into a nationally mandated means to ensure consistent approaches to emergency incidents. As NIMS/ICS has become federally mandated (Bush, 2003) with a requirement placed on all surface transit agencies receiving federal preparedness funds it has become necessary to find the most effective manner to deliver training to operation line employees at those agencies.

This suggests the necessity for a deeper, nationwide assessment of the current training methods employed at surface transit agencies; this study has merely scratched the surface by sampling regional transit agencies with a brief questionnaire. This research, though limited in scope, has provided an essential glimpse into the training practices at the surveyed agencies, and should serve to create more interest in finding ways to improve andragogy at transit agencies and ensure the stability of the nation's infrastructure. Further, based on the limited number surveyed in this study it is suggested that more research should be done to establish more concretely an effective training delivery method, with some attention paid to a blended method as indicated by agency response/interest.

Finally, it is suggested that transit agencies consider the incorporation of the TRB packet to assist in both training, and field response, as it provides the essential elements that trainees need to more effectively learn the material and respond to emergency incidents. Because of the 
noted modularity, and mobility unique to the TRB packet as a platform, it is well suited to deployment at any transportation agency and should be considered a valuable addition to any current training practices at surface transit agencies. Further, the packet has a current, well developed body of support and information that allows rapid construction and field use. While it has yet to be a common tool in service at surface transit agencies, exposure to the packet and what it offers will provide agencies a new asset they may employ both in training and incident response that comes with a relatively shallow learning curve and can be largely be assembled with components common to any office environment. 


\section{SOURCES CITED}

Annelli, J. (2006). The National Incident Management System: a multi-agency approach to emergency response in the United States of America. Revue Scientifique et Technique de 1ole, 25(1), 223-231. doi:10.20506/rst.25.1.1656

Buch, K., \& Bartley, S. (2002). Learning style and training delivery mode preference. Journal of Workplace Learning, 14(1), 5-10. doi:10.1108/13665620210412795

Bush, G. W. (2003, March). HSPD-5 Homeland Security Directive - 5. Retrieved from https://www.dhs.gov/publication/homeland-security-presidential-directive-5

Butler, D. (2012). Focusing Events in the Early Twentieth Century: A Hurricane, Two Earthquakes, and a Pandemic. In C. Rubin. Editor (Ed.), Emergency Management: The American Experience 1900-2010 (pp. 13-50). Boca Raton, FL USA: CRC Press.

Clarke, A., Lewis, D., Cole, I., \& Ringrose, L. (2012). A strategic approach to developing elearning capability for healthcare. Health Information and Libraries Journal, 22(2), 3341.

Department of Homeland Security (2011). National Incident Management System Training Program Retrieved from https://www.fema.gov/pdf/emergency/nims/nims_training_program.pdf

Edwards, F. L., \& Goodrich, D. C. (2014). Exercise Handbook: What Transportation Security and Emergency Preparedness Leaders Need to Know to Improve Emergency Preparedness. Report \#12-08 San Jose, CA: Mineta Transportation Institute. http://transweb.sjsu.edu/PDFs/research/1103-transportation-security-emergencypreparedness-handbook.pdf 
Edwards, F.L. \& Goodrich, D.C. (2016). Incident Command System (ICS) Training for FieldLevel Supervisors and Staff. NCHRP 20-59 (30). [downloadable materials]. http://www.trb.org/Main/Blurbs/173984.aspx

Edwards, F., Goodrich, D.C, \& Griffith, J. (2016). Emergency Management Training for Transportation Agencies. Report \#12-70 San Jose, CA: Mineta Transportation Institute. http://transweb.sjsu.edu/PDFs/research/1280-emergency-management-training-fortransportation-agencies.pdf

Edwards, F. L., Goodrich, D. C., \& Griffith, J. (2016). Incident Command System (ICS) Training for Field-Level Supervisors and Staff. NCHRP 20-59 (30). [report] doi:10.17226/23411.

FEMA. (2004). NIMS and the Incident Command System. ICS Position Paper. November 23. Retrieved March 21, 2018, from https://www.fema.gov/txt/nims/nims_ics_position_paper.txt

Golobish, J. (2012). FEMA ICS Organization. Retrieved March 24, 2018, from https://training.fema.gov/emiweb/is/icsresource/assets/icsorganization.pdf

Hambridge, N. B., Howitt, A. M., \& Giles, D. W. (2017). Coordination in Crises: Implementation of the National Incident Management System by Surface Transportation Agencies. Homeland Security Affairs, Volume 13 (April) https://www.hsaj.org/articles/13773

Harrald, J. R. (2012). Emergency Management Restructured: Intended and unintended Outcomes of Actions Taken since 9/11. In C. Rubin. Editor (Ed.), Emergency Management: The American Experience 1900-2010 (pp. 167-189). Boca Raton, FL USA: CRC Press.

Howitt, A. M., \& Leonard, H. B. (2009). Managing Crises: Responses to Large-Scale Emergencies. Washington D.C: CQ Press. 
Levett-Jones, T. L. (2005). Self-directed learning: Implications and limitations for undergraduate nursing education. Nurse Education Today, 25(5), 363-368. doi:

10.1016/j.nedt.2005.03.003

Lim, D. H., Morris, M. L., \& Kupritz, I. W. (2014). Online Vs. Blended Learning: Differences in instructor outcomes and learner satisfaction. Retrieved from https://files.eric.ed.gov/fulltext/EJ842695.pdf

Means, B., Toyama, Y., Murphy, R., \& Bakie, M. (2013). The Effectiveness of Online and Blended Learning: A Meta-Analysis of the Empirical Literature. Teachers College Record, 115.

Merriam-Webster. (2018). Andragogy. Retrieved March 19, 2018, from https://www.merriamwebster.com/dictionary/andragogy

Mileti, D. S. (2004). Disasters by Design: A Reassessment of Natural Hazards in The United States. Washington, DC: Henry.

Moynihan, Donald P. (2008) The network governance of crisis response: Case studies of incident command systems. SSRN Electronic Journal. doi:10.2139/ssrn.1311597.

Neamy, Robert (2011) From Firescope to NIMS. Fire Rescue. August. www.firerescuemagazine.com/articles/print/volume-6/issue-8/command-andleadership/from-firescope-to-nims.html

Nicholson, W. C., Esq. (2007). Legal Issues. In Waugh and Tierney (eds.) Emergency Management: Principles and Practice for Local Government, $2^{\text {nd }}$ edition. Washington, D.C.: ICMA Press.

Okasaki, N. W. (2003). Improving transportation response and security following a disaster. Institute of Transportation Engineers. Vol. 73, Issue. 8 (August) 
Rubin, C. B. (2012). Emergency Management: The American Experience, 1900-2010. Boca Raton, FL: CRC Press.

Schmidt, S. W. (2007). The relationship between satisfaction with workplace training and overall job satisfaction. Human Resource Development Quarterly, 18(4), 481-498. doi:10.1002/hrdq.1216

Sylves, R. T. (2015). Disaster Policy and Politics: Emergency Management and Homeland Security. Washington, DC: CQ Press.

Sylvia, R. D., \& Sylvia, K. M. (2012). Program Planning and Evaluation for The Public Manager. Long Grove, Illinois: Waveland Press.

Waugh, W. L. (2000). Living with Hazards, Dealing with Disasters: An Introduction to Emergency Management. Armonk, NY: M.E. Sharpe.

Waugh, W. L., \& Tierney, K. J. (2007). Emergency Management: Principles and Practice for Local Government, $2^{\text {nd }}$ edition. Washington, D.C.: ICMA Press.

Zmeyov, S. I. (1998). Andragogy: Origins, developments, and trends. International Review of Education, 44(1), 103-108. doi:10.1023/A:1003107931006 


\section{APPENDIX: ICS Kit Components}

\section{Current TRB Kit/Packet Elements}

(1)

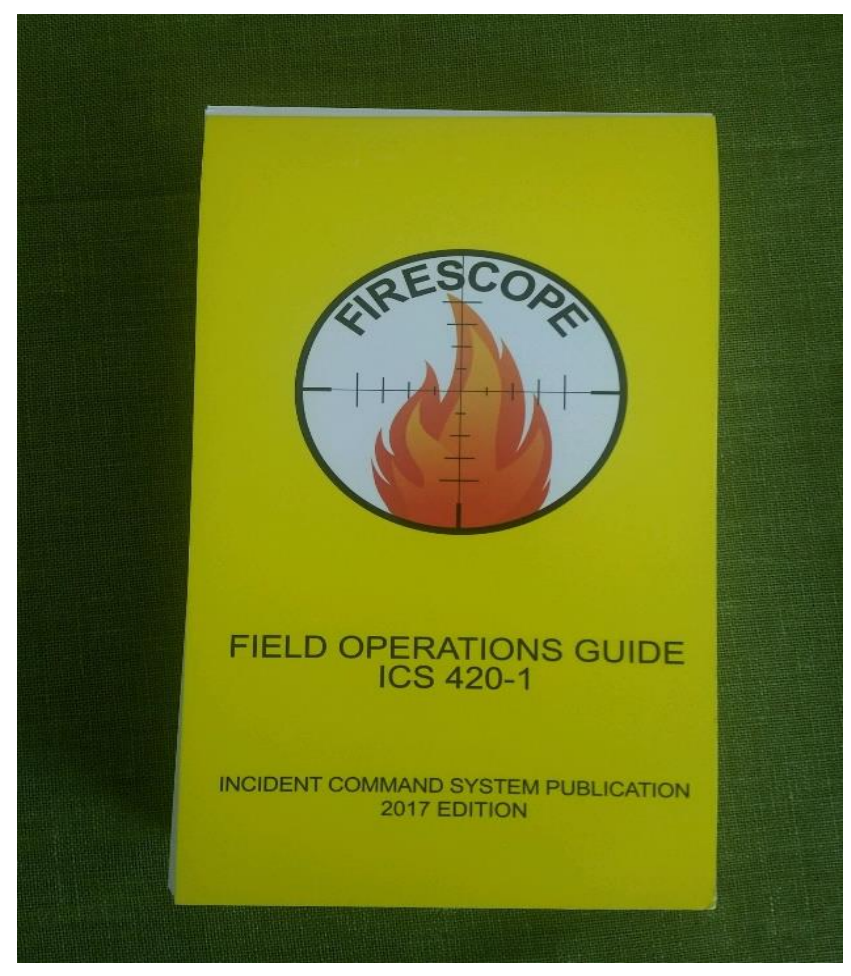

Firescope ICS guidebook printed in the state of California. The Firescope Field Operations Guide is included in the TRB packet as a reference guide that is durable and field deployable. It is a central component of the TRB packet (1)

Photo courtesy of DC Goodrich, 2018. 
(2)

ICS TRB packet preparation materials prior to being assembled into the field deployable packet/kit. Displayed is the colored paper which will be printed with the instructions/actions expected of the person assuming each task. The sheets are color coordinated to make identification easier in the field.

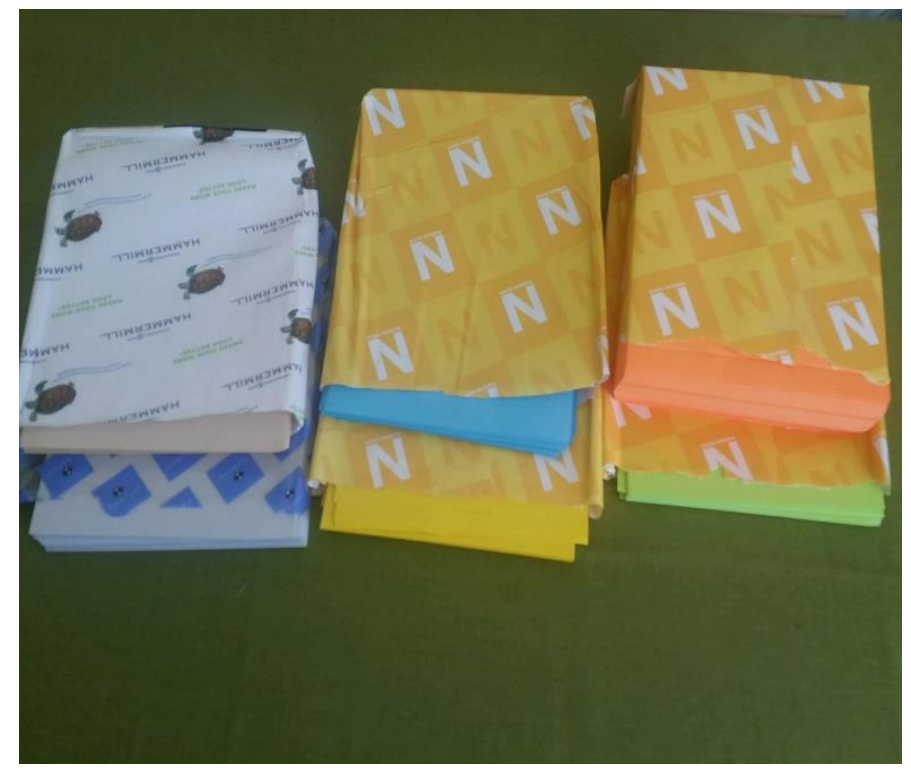

Photo courtesy of DC Goodrich, 2018) 
(3)

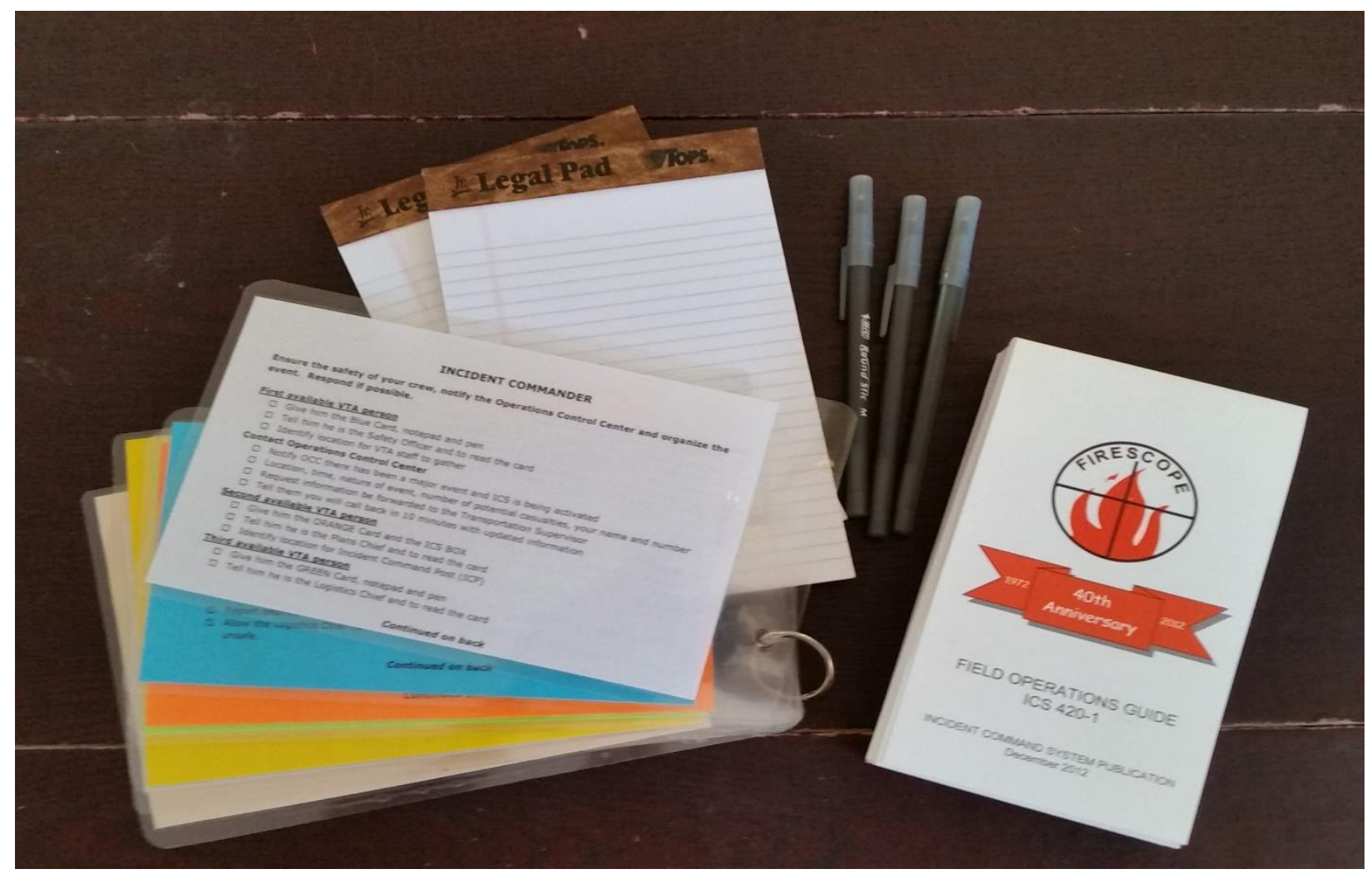

Photo courtesy of DC Goodrich, 2018

The colored paper (picture 2) now printed with section chief-specific instructions, then laminated for weather and use durability. The cards are front and back and provide the essential obligations of mission tasks that each section is charged with completing. The cards are accompanied by other TRB packet materials such as the Firescope booklet, miniature legal pads, and pens. 
(4)

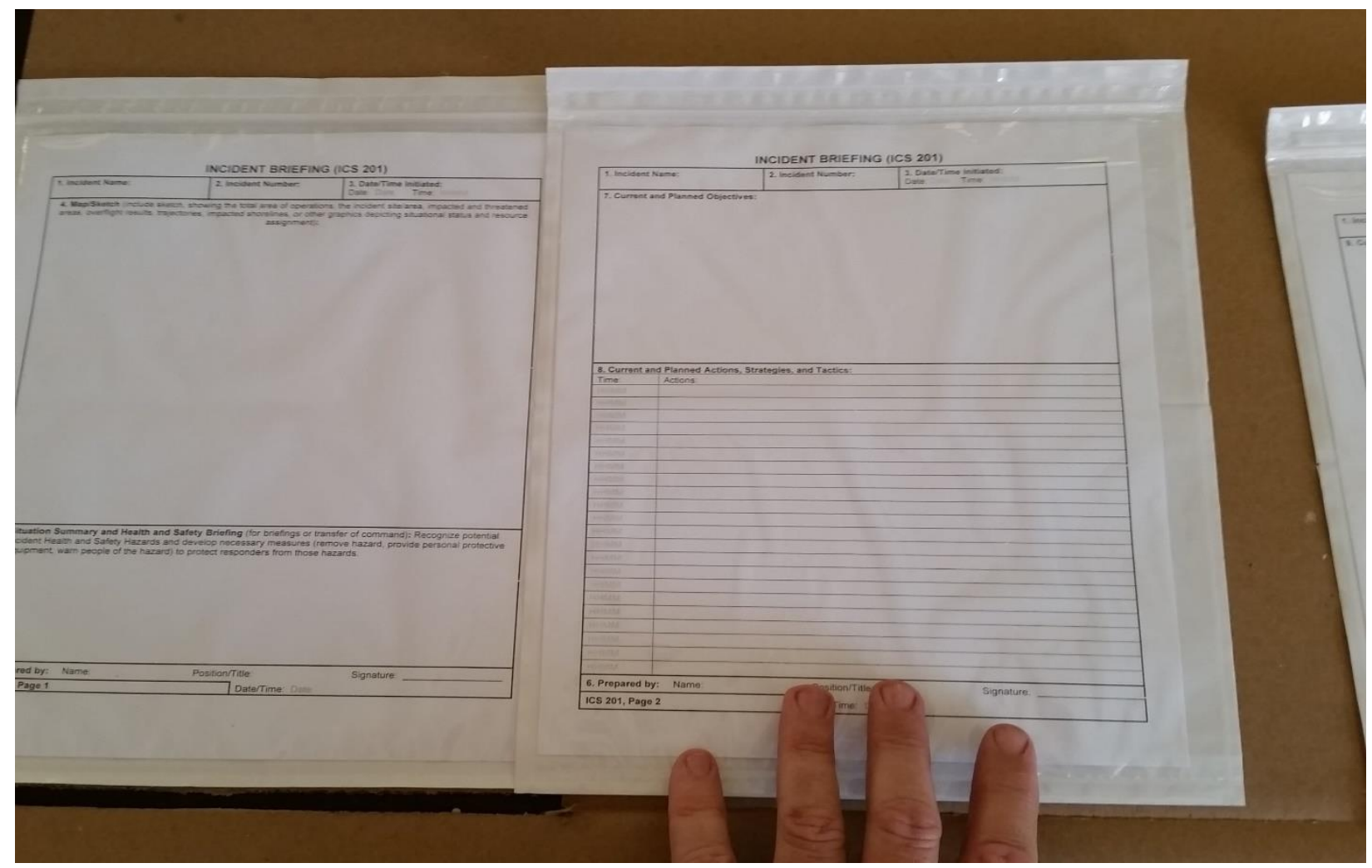

Photo courtesy of DC Goodrich, 2018

The TRB packet includes essential ICS paperwork, as well as basic instructions on how to complete them. When mounted with the included board, they allow information collection and sharing at virtually any incident (4) 
(5)

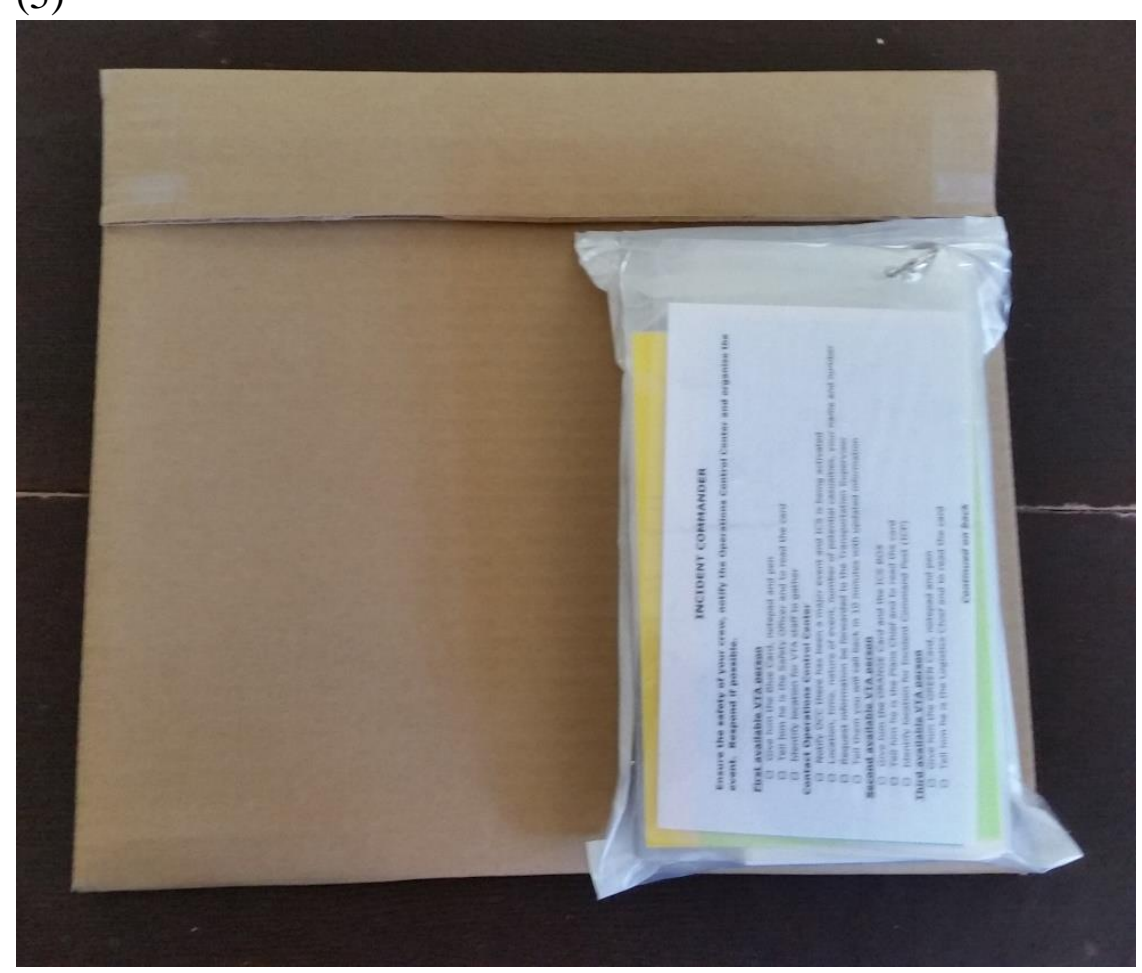

The ICS cards, legal pads, pens, and Firescope booklet as they are included with the TRB packet sealed in a weather resistant case along with the closed TRB kit (5)

Photo courtesy of DC Goodrich, 2018 
(6)

A completed TRB/ICS packet/kit which has been closed for easy carry in the field, or to the classroom (6)

The mobility of the kit, as well as its adaptability make an ideal accompaniment to both training and field applications

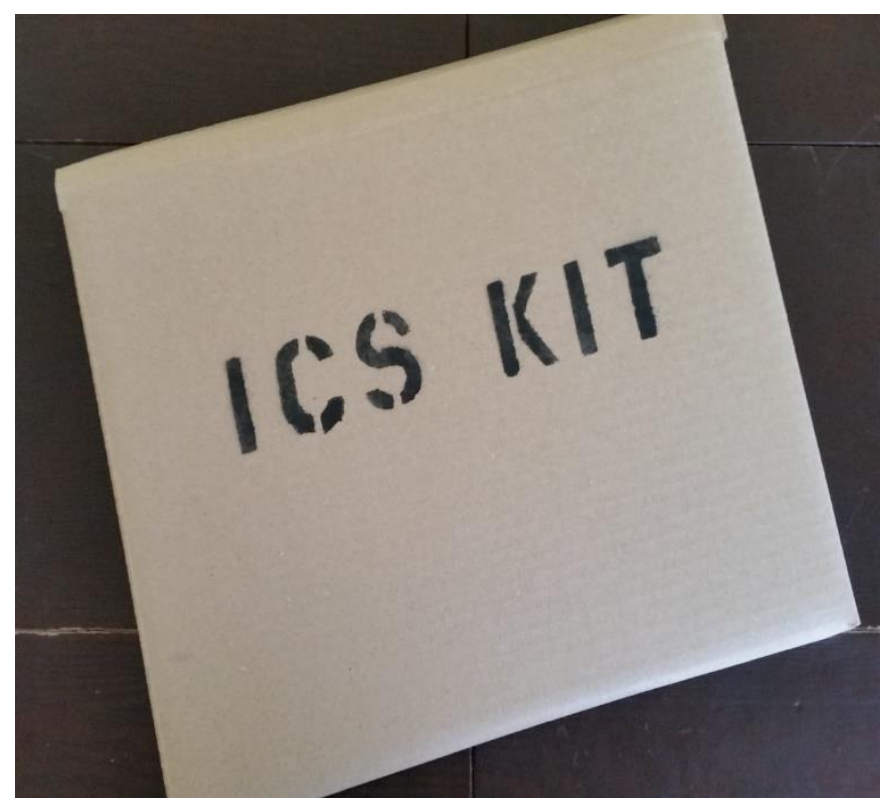

Photo courtesy of DC Goodrich, 
(7)

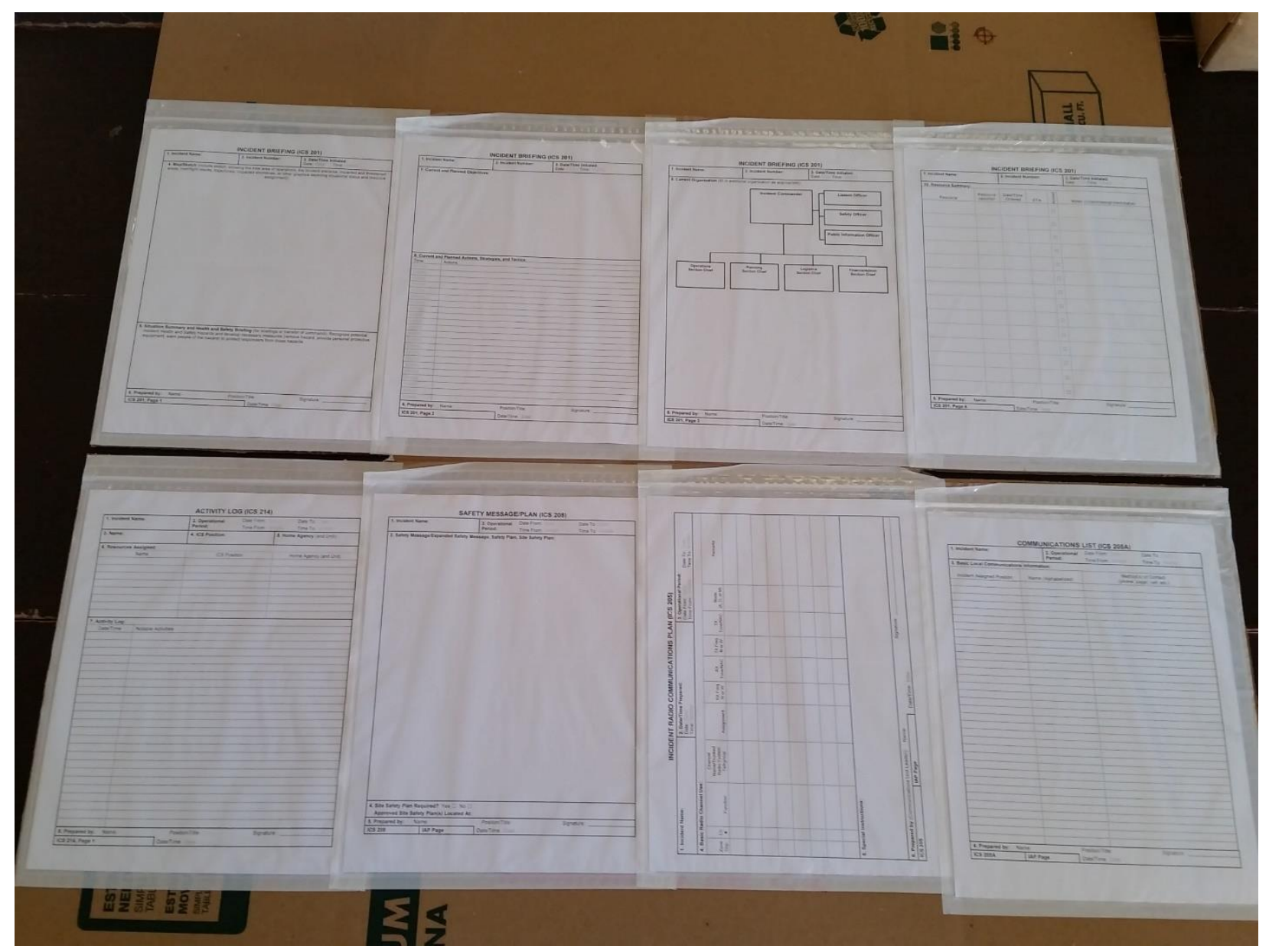

Photo courtesy of DC Goodrich, 2018

The completed TRB packet/kit opened to display all the ICS forms for review by the Incident Commander (IC), or other sections chiefs (7)

This design can easily be mounted in a variety of ways for easy access in both training/education, and in the field. 